\title{
Estimates of biomass burning emissions in tropical Asia based on satellite-derived data
}

\author{
D. Chang and Y. Song \\ State Key Joint Laboratory of Environmental Simulation and Pollution Control, Department of Environmental Sciences, \\ Peking University, Beijing 100871, China
}

Received: 14 July 2009 - Published in Atmos. Chem. Phys. Discuss.: 22 September 2009

Revised: 27 February 2010 - Accepted: 1 March 2010 - Published: 8 March 2010

\begin{abstract}
Biomass burning in tropical Asia emits large amounts of trace gases and particulate matter into the atmosphere, which has significant implications for atmospheric chemistry and climatic change. In this study, emissions from open biomass burning over tropical Asia were evaluated during seven fire years from 2000 to 2006 (1 March 2000-31 February 2007). The size of the burned areas was estimated from newly published 1-km L3JRC and 500-m MODIS burned area products (MCD45A1). Available fuel loads and emission factors were assigned to each vegetation type in a GlobCover characterisation map, and fuel moisture content was taken into account when calculating combustion factors. Over the whole period, both burned areas and fire emissions showed clear spatial and seasonal variations. The size of the L3JRC burned areas ranged from $36031 \mathrm{~km}^{2}$ in fire year 2005 to $52303 \mathrm{~km}^{2}$ in 2001, and the MCD45A1 burned areas ranged from $54790 \mathrm{~km}^{2}$ in fire year 2001 to $148967 \mathrm{~km}^{2}$ in 2004. Comparisons of L3JRC and MCD45A1 burned areas using ground-based measurements and other satellite data were made in several major burning regions, and the results suggest that MCD45A1 generally performed better than L3JRC, although with a certain degree of underestimation in forest areas. The average annual L3JRC-based emissions were 123 (102-152), 12 (9-15), 1.0 (0.7-1.3), 1.9 (1.4-2.6), $0.11(0.09-0.12), 0.89$ (0.63-1.21), 0.043 (0.0360.053), 0.021 (0.021-0.023), 0.41 (0.34-0.52), 3.4 (2.6-4.3), and $3.6(2.8-4.7) \mathrm{Tg} \mathrm{yr}^{-1}$ for $\mathrm{CO}_{2}, \mathrm{CO}, \mathrm{CH}_{4}, \mathrm{NMHC}_{\mathrm{s}}, \mathrm{NO}_{\mathrm{x}}$, $\mathrm{NH}_{3}, \mathrm{SO}_{2}, \mathrm{BC}, \mathrm{OC}, \mathrm{PM}_{2.5}$, and $\mathrm{PM}_{10}$, respectively, whereas MCD45A1-based emissions were 122 (108-144), 9.3 (7.711.7), 0.63 (0.46-0.86), 1.1 (0.8-1.6), 0.11 (0.10-0.13), 0.54 (0.38-0.76), $0.043(0.038-0.051), 0.033(0.032-0.037), 0.39$
\end{abstract}

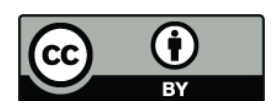

Correspondence to: Y. Song (songyu@pku.edu.cn)
(0.34-0.47), 3.0 (2.6-3.7), and $3.3(2.8-4.0) \mathrm{Tg} \mathrm{yr}^{-1}$. Forest burning was identified as the major source of the fire emissions due to its high carbon density. Although agricultural burning was the second highest contributor, it is possible that some crop residue combustion was missed by satellite observations. This possibility is supported by comparisons with previously published data, and this result may be due to the small size of the field crop residue burning. Fire emissions were mainly concentrated in Indonesia, India, Myanmar, and Cambodia. Furthermore, the peak in the size of the burned area was generally found in the early fire season, whereas the maximum fire emissions often occurred in the late fire season.

\section{Introduction}

Biomass burning is an important source of atmospheric trace gases and particulate matter, which may exert a significant influence on climate and atmospheric chemistry, particularly in the tropics (Seiler and Crutzen, 1980; Hao and Liu, 1994). Fires are widely used in tropical regions for deforestation, shifting cultivation, and clearance of agricultural residue (Crutzen and Andreae, 1990; Hao et al., 1990). In the tropics, both the surface vegetation and the underlying peat constitute large and highly concentrated carbon pools (Brown et al., 1993). Previous studies have statistically evaluated the carbon released from tropical biomass burning and found that it varied between 1.8 and $4.7 \mathrm{Pg} \mathrm{yr}^{-1}$ (Seiler and Crutzen, 1980; Crutzen and Andreae, 1990; Hao et al., 1990; Hao and Liu, 1994). Recently, many studies evaluating fire emissions have taken advantage of satellite data products, e.g., the AVHRR fire count product (Setzer and Pereira, 1991), GBA2000 product (Ito and Penner, 2004; Korontzi, 2005),

Published by Copernicus Publications on behalf of the European Geosciences Union. 
VIRS fire count product and MODIS burned-area dataset (Ito et al., 2007). However, many of these studies were primarily conducted in Africa and Amazonia.

Tropical Asia is considered to be the highest biomassburning region in Asia and has experienced some of the most severe wildland fire events under extreme climatic conditions (Chandra et al., 2002; Page et al., 2002; Streets et al., 2003). In addition, the peatland area in Southeast Asia covers approximately 26 million ha, accounting for $69 \%$ of all tropical peatland (Rieley and Page, 2005). Approximately 26-50 Gt carbon has accumulated in this peatland over thousands of years, and it thus represents an important carbon sink (Page et al., 2002). Due to major changes in land-use and particularly through extensive wildfires, a significant fraction of this will be released into the atmosphere (Shimada et al., 2000). The total amount of carbon emitted per year via the burning of tropical Asian biomass has been estimated at $238 \mathrm{Tg} \mathrm{yr}^{-1}$ in the 1990s (Streets et al., 2003), 62.8-99.7 $\mathrm{Tg} \mathrm{yr}^{-1}$ in 2000 (Hoelzemann et al., 2004; Ito and Penner, 2004; Kasischke and Penner, 2004), and $420 \mathrm{Tg} \mathrm{yr}^{-1}$ in the interval 19972004 (van der Werf et al., 2006). Some studies concerning biomass burning have been undertaken in specific regions throughout tropical Asia, e.g., in Indonesia (Page et al., 2002; Langner and Siegert, 2009) and in India (Venkataraman et al., 2006; Vadrevu et al., 2008). Streets et al. (2003) used published data to quantify the amount of emitted species from open biomass burning in Asia, and Michel et al. (2005) developed an emission inventory of Asian biomass burning based on the GBA2000 algorithm. In addition, van der Werf et al. (2008) estimated the fire emissions in equatorial Asia between 2000 and 2006 using Measurements of Pollution in the Troposphere (MOPITT). However, these studies were either limited in time or had a relatively coarse spatiotemporal resolution. Accordingly, a longer-term, higher-resolution study into the emissions from biomass burning in tropical Asia is required.

More recently, multi-year global burned-area products with medium spatial resolution $(1 \mathrm{~km}$ or $500 \mathrm{~m})$ and high temporal resolution have been released for public use: the L3JRC product (Tansey et al., 2008) and the MODIS burnedarea product (MCD45A1) (Roy et al., 2008). We used these two burned-area products to estimate the amount of certain emissions $\left(\mathrm{CO}_{2}, \mathrm{CO}, \mathrm{CH}_{4}, \mathrm{NMHC}_{\mathrm{s}}, \mathrm{NO}_{\mathrm{x}}, \mathrm{NH}_{3}, \mathrm{SO}_{2}, \mathrm{BC}\right.$, OC, $\mathrm{PM}_{2.5}$, and $\mathrm{PM}_{10}$ ) from open biomass burning in tropical Asia (see Fig. 1) for seven fire years between 2000 and 2006. In this study, each fire year represents the interval between March and the February of the following year (Boschetti and Roy, 2008). Both L3JRC- and MCD45A1based emission inventories have a high temporal resolution (daily) and medium spatial resolution of $1 \mathrm{~km}$ (L3JRC) or $500 \mathrm{~m}$ (MCD45A1) and can be used in the simulation of global and regional atmospheric chemistry.

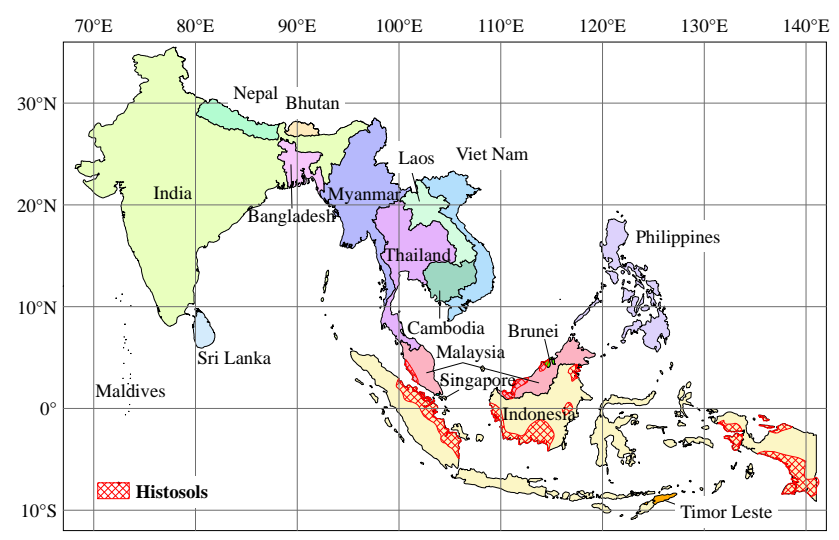

Fig. 1. Study area map and peat distribution based on WRB map (FAO, 2003).

\section{Method and dataset}

\subsection{Method}

The pollutants were mainly released by the burning of fine and coarse living tissue, fine litter, coarse woody debris (CWD), and soil organic carbon (SOC), and the method used to calculate emissions was based on the following equation described by Seiler and Crutzen (1980):

Emission $=A \times B \times \mathrm{CF} \times \mathrm{EF}$,

where $A$ denotes the area burned $\left(\mathrm{m}^{2}\right) ; B$ is the available fuel load $\left(\mathrm{kg} \mathrm{DM} \mathrm{m}^{-2}\right)$, which in our study was represented by the biomass density and mainly consisted of aboveground fine and coarse fuels (alive and dead) and SOC; CF (combustion factor) is the fraction of available fuels exposed to fires that are actually burned; and EF is the emission factor for the emitted pollutants (mass of species per mass of dry matter burned in $\mathrm{g} \mathrm{kg}^{-1}$ ).

The CFs and EFs are largely dependent on fuel type, moisture content, and the conditions under which combustion takes place (Shea et al., 1996; Hoffa et al., 1999). In grassland and woodland regions, fuel moisture was taken into account when estimating CFs for grass fuels. Ito and Penner (2005) developed the relationship between CFs and the percentage of green grass relative to total grass (PGREEN) based on measurements made at eight sites in Zambia between June and September. The Normalised Difference Vegetation Index (NDVI) was used to determine PGREEN following Eq. (2) (Kogan, 1997; Burgan et al., 1998):

$\mathrm{PGREEN}_{t}=\left(\mathrm{NDVI}_{t}-\mathrm{NDVI}_{\min }\right) /\left(\mathrm{NDVI}_{\max }-\mathrm{NDVI}_{\min }\right)$,

where $t$ denotes the month, and $\mathrm{NDVI}_{\min }$ and $\mathrm{NDVI}_{\max }$ are the minimum and maximum of all NDVI values for a given pixel over the preceding growing season. The NDVI data were derived from the MODIS Vegetation Indices Monthly L3 Global 1-km product (MOD13A3). Missing NDVI data 
were replaced with the average values for the same month from the other years. For the pixels with consistently high or low NDVI values (e.g., equatorial evergreen forests or deserts), the NDVI-based method to assess PGREEN was found to be unreliable (Korontzi, 2005). However, if these pixels were labelled as burned by the L3JRC or MCD45A1 products, their PGREEN values were defined as the mean of all PGREEN values for this pixel over the whole fire year. Previous field measurements suggested that coarse woodland fuels (living woody biomass and CWD) combust when the CF for fine fuels is greater than 47\% (Hoffa et al., 1999). In this study, a similar CF of 0.3 was used for coarse fuels in woodland regions (Ito and Penner, 2004). In forested regions, defined as areas with tree cover greater than $60 \%$, it was assumed both fine fuels and coarse fuels were burned, so CFs of 0.90 and 0.27 were applied, respectively (Ito and Penner, 2004).

EFs have been measured for multiple species in laboratories, and in airborne and ground-based field studies, and strong seasonality within biomes has been shown (e.g., Shea et al., 1996; Ferek et al., 1998; Yokelson et al., 2007). In this study, the EFs used for various compounds were based on laboratory measurements of representative Indonesian fuel fires (peat, secondary forest floor litter, semak, alang-alang, and rice straw) (Christian et al., 2003). For EFs from nonagricultural fires not included in the study by Christian et al. (2003), the values from fires in Brazil were applied, as the Brazilian ecosystem was considered to be representative of the ecosystem in Indonesia (Ferek et al., 1998; Christian et al., 2003). For crop residue burning, we used EFs determined for developing countries (Yevich and Logan, 2003). When the EFs for certain emitted species were excluded in the afore-mentioned publications, the results compiled in Andreae and Merlet (2001), which reviewed a number of studies and compiled EFs for over 100 trace gas species, were used instead. Summary of the EFs used in this study is listed in Table 1.

\subsection{Dataset}

\subsubsection{Burned area}

In this paper, the L3JRC burned-area product and the Collection 5 MODIS (MCD45A1) burned-area product were used to define the area burned in tropical Asia for seven fire years from 2000-2006.

The L3JRC product was derived from SPOT VEGETATION sensor detections that have medium spatial $(1-\mathrm{km})$ and high temporal resolution (daily intervals). A single algorithm was used to classify burned areas from SPOT VEGETATION reflectance data. The algorithm was successfully used over a wide geographical area and on various vegetation types, and it could be adapted for application on a global scale. The L3JRC product has been evaluated globally against a large number of Landsat TM and ETM+ image pairs and a number of regional products derived from in situ or remote means. Thirteen reference data sets within the Southern Asia region and Australia (below $35^{\circ} \mathrm{N}$ and $50^{\circ} \mathrm{E}$ ) were reviewed, and the validation results showed that the L3JRC product could only map $46 \%$ of the area burned (Tansey et al., 2008).

The MCD45A1 product uses a change detection algorithm based on a bidirectional reflectance model-based expectation method to map the location and approximate date of burning at 500-m resolution (Roy et al., 2002). Validation of the MCD45A1 product has been performed during the 2001 fire season for 11 locations in southern Africa using Landsat ETM+ data (Roy and Boschetti, 2009). Results showed that the MCD45A1 product was capable of capturing $75 \%$ of the burned area detected by Landsat data. Comparisons with L3JRC and GLOBCARBON Burnt Area Estimate (BAE) products (European Space Agency, 2006) suggested that MCD45A1 achieved the highest degree of accuracy, followed by GLOBCARBON, and then by L3JRC (Roy and Boschetti, 2009).

\subsubsection{Land cover characterisation}

We used the European Space Agency (ESA) GlobCover land cover product (http://ionia1 .esrin.esa.int/index.asp) to define the vegetation type in the studied region and to remove nonvegetated surfaces (e.g., water, snow, deserts, and urban areas) as a mask. At present, this product is the highestresolution (300-m) global land cover dataset available and covers the period from December 2004 to June 2006. GlobCover is derived from an automatic and regionally tuned classification of the Medium-Resolution Imaging Spectrometer (MERIS) full-resolution (FR) time series. The regional land cover product for Asia has 43 land cover classes, the definitions of which are based on the United Nations' Land Cover Classification System (LCCS) (Bicheron et al., 2008). Within our work, the 43 vegetation classes were grouped into five broad categories: forest (including broadleaf evergreen, broadleaf deciduous, needleleaf evergreen, needleleaf deciduous, and mixed forest); shrubland (broadleaf or needleleaf, evergreen or deciduous shrubland); grassland (closed/open grassland, mosaic vegetation, sparse vegetation); cropland (post-flooding or irrigated croplands, rainfed croplands, and mosaic cropland/vegetation); and other (including bare areas, water bodies, snow and ice, artificial surfaces and associated areas).

The MODIS Vegetation Continuous Fields product (VCF) was used to provide proportional estimates of vegetative cover types: woody vegetation, herbaceous vegetation, and bare ground. This product was derived from all seven 500-m bands of the MODIS sensor onboard NASA's Terra satellite and had a spatial resolution of $500 \mathrm{~m}$ (Hansen et al., 2003). Furthermore, this dataset was overlaid onto the GlobCover vegetation characterisation map to more accurately define the land cover type in each pixel. 
Table 1. Emission factors for different species.

\begin{tabular}{lrrrrr}
\hline Vegetation type & Forest $^{\mathrm{a}}$ & Shrubland $^{\mathrm{a}}$ & Grassland $^{\mathrm{a}}$ & Cropland $^{\mathrm{a}}$ & Peat area $^{\mathrm{b}}$ \\
\hline $\mathrm{CO}_{2}{ }^{\mathrm{c}}$ & 1618 & 1567 & 1629 & 1132 & 3113 \\
$\mathrm{CO}^{\mathrm{c}}$ & 113 & 122 & 51.6 & 51 & 384 \\
$\mathrm{CH}_{4}{ }^{\mathrm{c}}$ & 5.3 & 6.4 & 0.9 & 2.2 & 38 \\
$\mathrm{NMHC}_{\mathrm{s}}{ }^{\mathrm{d}}$ & 8.1 & 3.4 & 3.4 & 7.0 & 77 \\
$\mathrm{NO}_{\mathrm{x}}{ }^{\mathrm{c}}$ & 1.7 & 1.6 & 1.1 & 1.1 & 1.8 \\
$\mathrm{NH}_{3}{ }^{\mathrm{e}}$ & 2.9 & 5.0 & 0.7 & 4.1 & 36 \\
$\mathrm{SO}_{2}{ }^{\mathrm{d}}$ & 0.57 & 0.80 & 0.35 & 0.40 & 1.1 \\
$\mathrm{BC}^{\mathrm{f}}$ & 0.66 & 0.35 & 0.65 & 0.69 & 0.07 \\
$\mathrm{OC}^{\mathrm{f}}$ & 6.8 & 3.0 & 5.1 & 3.3 & 11. \\
$\mathrm{PM}_{2.5}{ }^{\mathrm{g}}$ & 61.6 & 39.2 & 6.6 & 3.9 & 108 \\
$\mathrm{PM}_{10}{ }^{\mathrm{g}}$ & 67.0 & 42.6 & 7.2 & 4.2 & 116 \\
\hline
\end{tabular}

${ }^{a}$ Units are gram species per kilogram of dry biomass burned.

$\mathrm{b}$ Units are gram species per kilogram of carbon burned.

c Values are derived from Christian et al. (2003), and Yevich and Logan (2003).

$\mathrm{d}$ Values are derived from Andreae and Merlet (2001).

e Values are from Christian et al. (2003).

${ }^{\mathrm{f}}$ Values are from Andreae and Merlet (2001), Christian et al. (2003), and Ferek et al. (1998).

$\mathrm{g}$ Values are from Andreae and Merlet (2001), Christian et al. (2003), and Heil (2007).

The World Reference Base (WRB) Map of World Soil Resources (FAO, 2003) was used to define the distribution of peat soils. According to the FAO soil classification, peat soils are referred to as histosols (HS), which are defined as having an organic (histic) soil horizon of at least $40 \mathrm{~cm}$. The spatial distribution of peat soils in tropical Asia is illustrated in Fig. 1.

\subsubsection{Fuel load}

Biomass density estimates for tropical Asian forests were modelled by Brown et al. (1993) using a geographic information system. Hao and Liu (1994) and Streets et al., 2003) relied on the biomass density estimations in Brown et al. (1993) to determine emissions from tropical Asian biomass burning. Ito and Penner (2004) calculated the horizontal distribution of biomass density based on a tree cover data set and potential biomass density data derived by Brown et al. (1993). Brown (1997) assessed the forest biomass density of developing countries in the tropics using existing inventories, and this method of estimation showed greater reliability for national and global evaluations of the quantity of forest resources. In this study, the density data for forest biomass in Bangladesh, Cambodia, Malaysia, Myanmar, Philippines, and Sri Lanka were taken from the results evaluated by Brown (1997) (Table 2). The district-level biomass density data in Indian forests were provided by Chhabra and Dadhwal (2004), and the forest biomass information for Nepal was provided by Shrestha and Singh (2008) (Table 2). In addition, the biomass density values for countries that were not included within the above publications were complemented by the data from Brown et al. (1993) (Table 2).
Previous studies indicated that CWD and litterfall were generally overlooked as potentially significant carbon stores in forested ecosystems (Harmon and Hua, 1991; Matthews, 1997; Liu et al., 2003). Therefore, we used the living tree biomass data to estimate the CWD pool based on the ratio of CWD to live tree biomass reported by Harmon and Hua (1991). They suggested that the ratio was 5\% for tropical rain forests, shrublands, and grasslands, and was between 20 and $25 \%$ for subtropical, temperate, and boreal forests (Matthews, 1997). We used the global average litterfall densities for different forest types compiled by Liu et al. (2003), except for India, where the district-specific estimates from Chhabra and Dadhwal (2004) were used.

The amount of biomass in the grass layer depends on local annual rainfall (Hao et al., 1990; Ito and Penner, 2004). Singh and Yadava (1974) analysed the seasonal variation in plant biomass of tropical grasslands in India and determined that the monthly aboveground biomass ranged from $0.105 \mathrm{~kg} \mathrm{~m}^{-2}$ in December to $1.974 \mathrm{~kg} \mathrm{~m}^{-2}$ in September. In our study, an average value of $0.797 \mathrm{~kg} \mathrm{~m}^{-2}$ was used as the mean grass biomass in India. Hashimotio et al. (2000) measured the biomass density of alang-alang grassland in Borneo between June 1993 and October 1994, and the mean value was $0.336 \mathrm{~kg} \mathrm{~m}^{-2}$. Therefore, this study used $0.336 \mathrm{~kg} \mathrm{~m}^{-2}$ as the mean grass biomass density value for the Indonesia and Malaysia region (Table 2). Because the updated grass cover biomass density data for the other tropical Asian countries were limited, an average value of $0.62 \mathrm{~kg} \mathrm{~m}^{-2}$ was used (Table 2), which is a typical dry-matter density for grass loading on a global scale (Christian et al., 2003). 
Table 2. Average aboveground biomass density $\left(\mathrm{kg}\right.$ dry matter $\mathrm{m}^{-2}$ ) for each country in tropical Asia.

\begin{tabular}{lrrrr}
\hline Vegetation type & Forest $^{\mathrm{a}}$ & Shrubland $^{\mathrm{b}}$ & Grassland $^{\mathrm{c}}$ & Cropland $^{\mathrm{d}}$ \\
\hline Bangladesh & 12 & 2.79 & 0.62 & 0.09 \\
Bhutan & 18 & 2.79 & 0.62 & 0.04 \\
Brunei & 32 & 2.79 & 0.34 & 0.01 \\
Cambodia & 19 & 2.79 & 0.62 & 0.09 \\
India & 9 & 2.79 & 0.80 & 0.07 \\
Indonesia & 32 & 2.79 & 0.34 & 0.27 \\
Laos & 27 & 2.79 & 0.62 & 0.21 \\
Malaysia & 31 & 2.79 & 0.34 & 0.04 \\
Maldives & 25 & 2.79 & 0.62 & 0.11 \\
Myanmar & 11 & 2.79 & 0.62 & 0.21 \\
Nepal & 21 & 2.63 & 0.10 & 0.13 \\
Philippines & 39 & 2.79 & 0.62 & 0.28 \\
Singapore & 25 & 2.79 & 0.62 & 0.04 \\
Sri Lanka & 40 & 2.79 & 0.62 & 0.11 \\
Thailand & 19 & 2.79 & 0.62 & 0.20 \\
Timor Leste & 14 & 2.79 & 0.62 & 0.21 \\
Vietnam & 26 & 2.79 & 0.62 & 0.37 \\
\hline
\end{tabular}

a Values are derived from Brown (1997), Brown et al. (1993), Chhabra and Dadhwal (2004), and Shrestha and Singh (2008).

$\mathrm{b}$ Values are derived from Shrestha and Singh (2008), and Venkataraman et al. (2006).

c Values are derived from Christian et al. (2003), Hashimotio et al. (2000), and Singh and Yadava (1974).

d Values are derived from FAO (2006), Koopmans and Koppejan (1997), and Yevich and Logan (2003).

The amount of dry-matter agricultural residue burned in open fields was determined from crop production, the residue-to-production ratios, and the percentage of drymatter residue that was burned in the field (Yevich and Logan, 2003). The crop production data for each country were gathered from the FAO Statistical Yearbook (FAO, 2006). For Asian countries, the percentage of agricultural residue burned in the field was reported by Yevich and Logan (2003), who also summarised the residue-to-production ratios for individual crops in developing countries. For those values that were not included in the study by Yevich and Logan (2003), we used the data from previous studies in Asia (Koopmans and Koppejan, 1997).

Peat combustion makes a large contribution to the total fire emissions in Southeast Asia, especially under EI Niño conditions (Boehm et al., 2001; Page et al., 2002). However, it is difficult to assess the peat quality (i.e., bulk density or carbon content) and the depths to which peat is burned; these uncertainties result in significant variability in emission estimates (Shimada et al., 2000; Page et al., 2002; Ito and Penner, 2004). Brown et al. (1993) assessed the tropical Asian SOC density based on the database of Zinke et al. (1984) and suggested a value of $14.8 \mathrm{~kg} \mathrm{C} \mathrm{m}^{-2}$ for a depth of $1 \mathrm{~m}$. Supardi et al. (1993) gave a biomass loading value of $97.5 \mathrm{~kg} \mathrm{~m}^{-2}$ for dry peat with a thickness of $1.5 \mathrm{~m}$. Batjes (1996) derived the average SOC density for different vertical depths on a global scale based on the World Inventory of Soil Emission Potential Database (WISE) profile dataset and the FAO Soil Map of the World. However, as these authors did not consider the regional differences in microclimate, parent material, and land use for soils, these data was not suitable for national evaluations (Batjes, 1996). Shimada et al. (2000) estimated that the carbon density ranged from $48.7 \mathrm{~kg} \mathrm{C} \mathrm{m}^{-3}$ to $87.8 \mathrm{~kg} \mathrm{C} \mathrm{m}^{-3}$ for different peatland types in Central Kalimantan, Indonesia. As these were recent studies, we also used a mean value of $63.65 \mathrm{~kg} \mathrm{C} \mathrm{m}^{-3}$ as the SOC density in equatorial Asian peatland. The combustion efficiency in peat is often expressed in terms of the thickness of peat burned away (Heil, 2007), which varied between $20-150 \mathrm{~cm}$ (Boehm et al., 2001) and $25-85 \mathrm{~cm}$ (Page et al., 2002) based on Indonesian field measurements. In our calculations, a single average peat burn depth of $51 \mathrm{~cm}$ was applied (Page et al., 2002).

\section{Results and discussion}

\subsection{Burned area}

Table 3 presents the burned area estimates derived from L3JRC and MCD45A1 products over seven fire years from 2000 to 2006. The annual mean L3JRC and MCD45A1 burned areas for these years were 43514 and $81556 \mathrm{~km}^{2} \mathrm{yr}^{-1}$, respectively. The interannual variations for these two burned-area products were also significantly different. The smallest L3JRC burned area occurred in 
Table 3. Total burned area and biomass burned derived from L3JRC and MCD45A1 burned-area products during seven fire years from 2000 to 2006 in tropical Asia ${ }^{\mathrm{a}}$.

\begin{tabular}{|c|c|c|c|c|c|c|c|c|}
\hline Fire year & 2000 & 2001 & 2002 & 2003 & 2004 & 2005 & 2006 & Average \\
\hline \multicolumn{9}{|c|}{ L3JRC } \\
\hline Forest & 6364,13 & 6803,18 & 4911,51 & 6122,27 & 5984,50 & 4763,48 & 4807,43 & 5679,36 \\
\hline Shrubland & 1831,4 & 2288,10 & 1649,21 & 2011,6 & 2656,23 & 1263,6 & 1540,13 & 1891,12 \\
\hline Grassland & 6203,6 & 6365,6 & 4185,5 & 5995,6 & 6139,7 & 3832,4 & 5440,7 & 5451,6 \\
\hline Cropland & 28810,12 & 36169,20 & 26282,29 & 33142,16 & 31187,29 & 25424,13 & 26717,22 & 29676,20 \\
\hline Other & $753,0.2$ & $679,0.2$ & $586,0.4$ & $1044,0.4$ & $854,0.3$ & $749,0.2$ & $1051,0.3$ & $816,0.3$ \\
\hline Total & 43961,36 & 52303,54 & 37613,108 & 48315,56 & 46821,109 & 36031,72 & 39554,85 & 43514,74 \\
\hline \multicolumn{9}{|c|}{ MCD45A1 } \\
\hline Fores & 7044,12 & 8057,17 & 7518,50 & 10553,21 & 14863,43 & 6202 , & 9790,29 & 9147,26 \\
\hline Shrubland & 3895,6 & 5553,10 & 4974,25 & 5933,9 & 13072,26 & 4829,8 & 8533,17 & 6684,14 \\
\hline Grassland & 6977,9 & 7011,7 & 6189,9 & 8487,12 & 12975,19 & 6232,8 & 8443,12 & 8045,11 \\
\hline Cropland & 39155,16 & 33805,16 & 45839,42 & 60346,24 & 107707,49 & 56980,15 & 58365,33 & 57457,28 \\
\hline Other & & & & & $350,0.19$ & .09 & $145,0.07$ & $223,0.09$ \\
\hline Total & 57210,43 & 54790,49 & 64799,126 & 85430,67 & 148967,136 & 74417,44 & 85277,91 & 81556,79 \\
\hline
\end{tabular}

a Burned area $\left(\mathrm{km}^{2}\right.$ ), biomass burned (Tg) (comma delimited). L3JRC data for March 2000 and MCD45A1 data for March 2000, June 2001 are missing.

the fire year 2005, and the largest in 2001. In contrast, the smallest and largest MCD45A1 burned areas were in the fire years 2001 and 2004, respectively. As shown in Fig. 2, the L3JRC burned areas were mainly concentrated in central India and eastern Cambodia, whereas, other than the extensive burning observed in India and Cambodia, the MCD45A1 product showed significantly more extensive burning in Myanmar and Thailand. Additionally, moderate burning was observed in the equatorial zone from the two products. For L3JRC, the burned area in India contributed $29228 \mathrm{~km}^{2} \mathrm{yr}^{-1}(67 \%)$, Myanmar contributed $3899 \mathrm{~km}^{2} \mathrm{yr}^{-1}(9 \%)$, Cambodia $3228 \mathrm{~km}^{2} \mathrm{yr}^{-1}$ (7\%), Nepal $2678 \mathrm{~km}^{2} \mathrm{yr}^{-1}$ (6\%), Indonesia $1669 \mathrm{~km}^{2} \mathrm{yr}^{-1}$ (4\%), and Thailand contributed $1287 \mathrm{~km}^{2} \mathrm{yr}^{-1}$ (3\%). For MCD45A1, the burned area occurring in India was also the largest, contributing $34184 \mathrm{~km}^{2} \mathrm{yr}^{-1}$ (42\%), followed by $16700 \mathrm{~km}^{2} \mathrm{yr}^{-1}(20 \%)$ from Myanmar, $12249 \mathrm{~km}^{2} \mathrm{yr}^{-1}$ (15\%) from Cambodia, and $11125 \mathrm{~km}^{2} \mathrm{yr}^{-1}$ (14\%) from Thailand. Burned areas in Indonesia and Nepal accounted for only approximately $2 \%\left(2008 \mathrm{~km}^{2} \mathrm{yr}^{-1}\right)$ and $0.5 \%$ $\left(429 \mathrm{~km}^{2} \mathrm{yr}^{-1}\right)$ of the total MCD45A1 burned area.

The annual estimates for the burned areas corresponding to each vegetation type are also summarised in Table 3 . The average annual L3JRC burned areas for forest, shrubland, grassland, and cropland were 5679 (13\%), 1891 (4\%), 5451 (12\%), and $29676 \mathrm{~km}^{2} \mathrm{yr}^{-1}(68 \%)$, respectively, whereas the corresponding average MCD45A1 burned areas were 9147 (11\%), $6684(8 \%), 8045(10 \%)$, and $57457 \mathrm{~km}^{2} \mathrm{yr}^{-1}(70 \%)$. Overall, the majority of the burned area in tropical Asia occurred within cropland, followed by forest, grassland, and then shrubland. The large area of burned cropland can be attributed to numerous fires related to slash-and-burn agricultural practices and land clearing, especially during particularly dry weather conditions. However, significant areas of agricultural burning may not have been detected because small agricultural fires are difficult to detect by satellites (Roy et al., 2008; Tansey et al., 2008). Forest fires were mostly associated with poor logging and with land being cleared for agricultural use in tropical regions (Crutzen and Andreae, 1990; Langner and Siegert, 2009). The GBA2000 database reported a burned area of $17000 \mathrm{~km}^{2}$ in forested regions (including an unspecified part of China) for the calendar year 2000 (Ito and Penner, 2004). The MCD45A1 burned area of $7044 \mathrm{~km}^{2}$ and the L3JRC burned area of $6364 \mathrm{~km}^{2}$ for forested land in the fire year 2000 were both typically smaller than the GBA2000 results. In addition, according to the peat distribution map provided by FAO (2003), an average L3JRC burned area of $674 \mathrm{~km}^{2} \mathrm{yr}^{-1}$ was measured within peat regions, whereas the mean area of burned land in peat, as shown by MCD45A1 was $317 \mathrm{~km}^{2} \mathrm{yr}^{-1}$. Furthermore, nearly all of the peat burning was observed in Indonesia. Indonesia is reported to possess approximately $80 \%$ of total peatland in Southeast Asia (Rieley and Page, 2005), and due to the damage caused by illegal logging and drainage, Indonesian peatland is more susceptible to fire, especially during the EI Niño period (Page et al., 2002; Langner and Siegert, 2009). Although the L3JRC and MCD45A1 burned areas in Indonesia were comparable $\left(1669 \mathrm{~km}^{2} \mathrm{yr}^{-1}\right.$ vs. $2008 \mathrm{~km}^{2} \mathrm{yr}^{-1}$ ), L3JRC showed more burning in peat areas than did MCD45A1. However, according to the ATSR fire count data provided by the RETRO inventory (reanalysis of the tropospheric chemical composition) over the past 

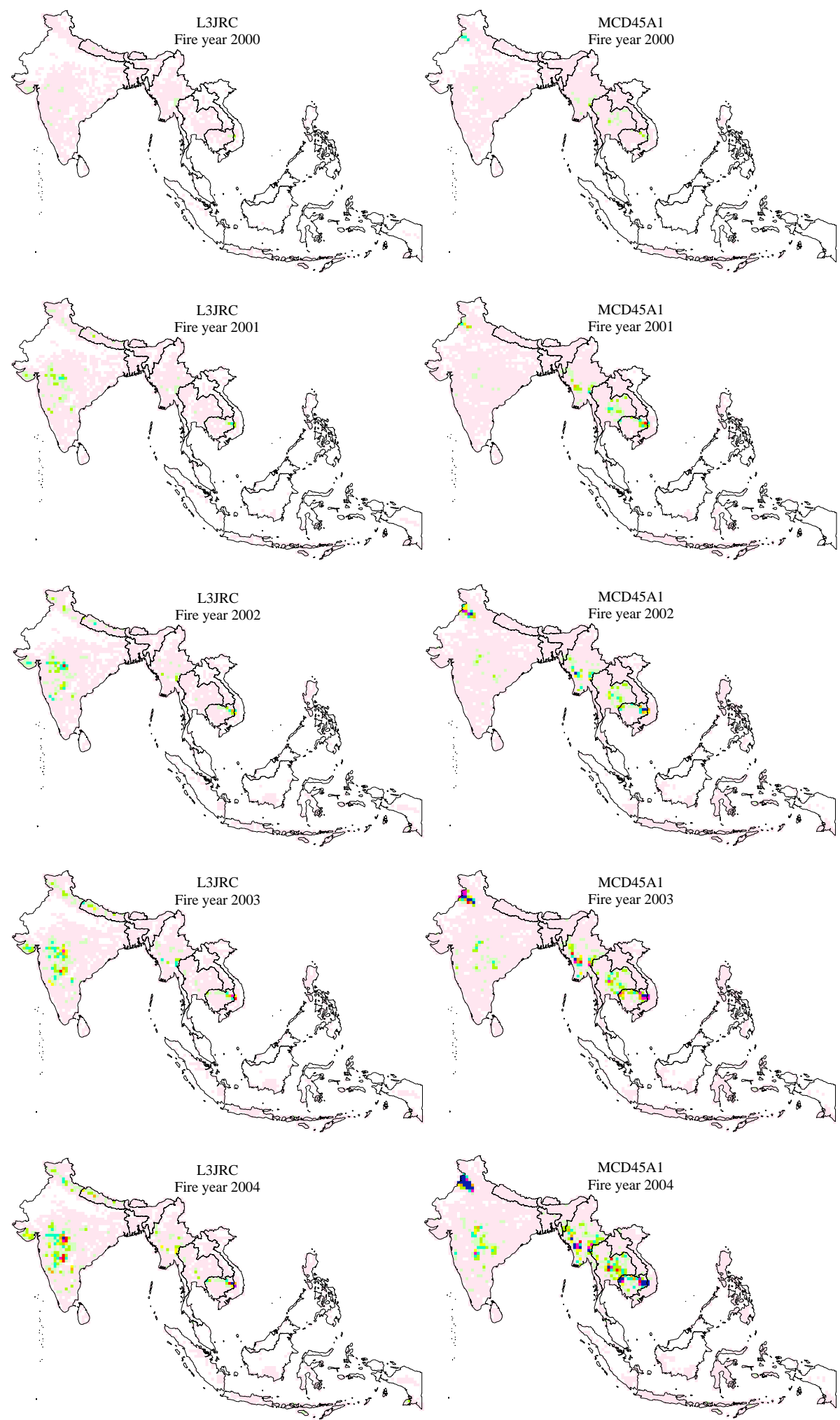

Fig. 2. Spatial distribution of L3JRC (left) and MCD45A1 (right) burned areas in tropical Asia during seven fire years (2000-2006) (L3JRC data for March 2000 and MCD45A1 data for March 2000, June 2001 are missing). Burned areas are illustrated by a colour scale according to the proportion of area burned per 0.5 -degree cell. 

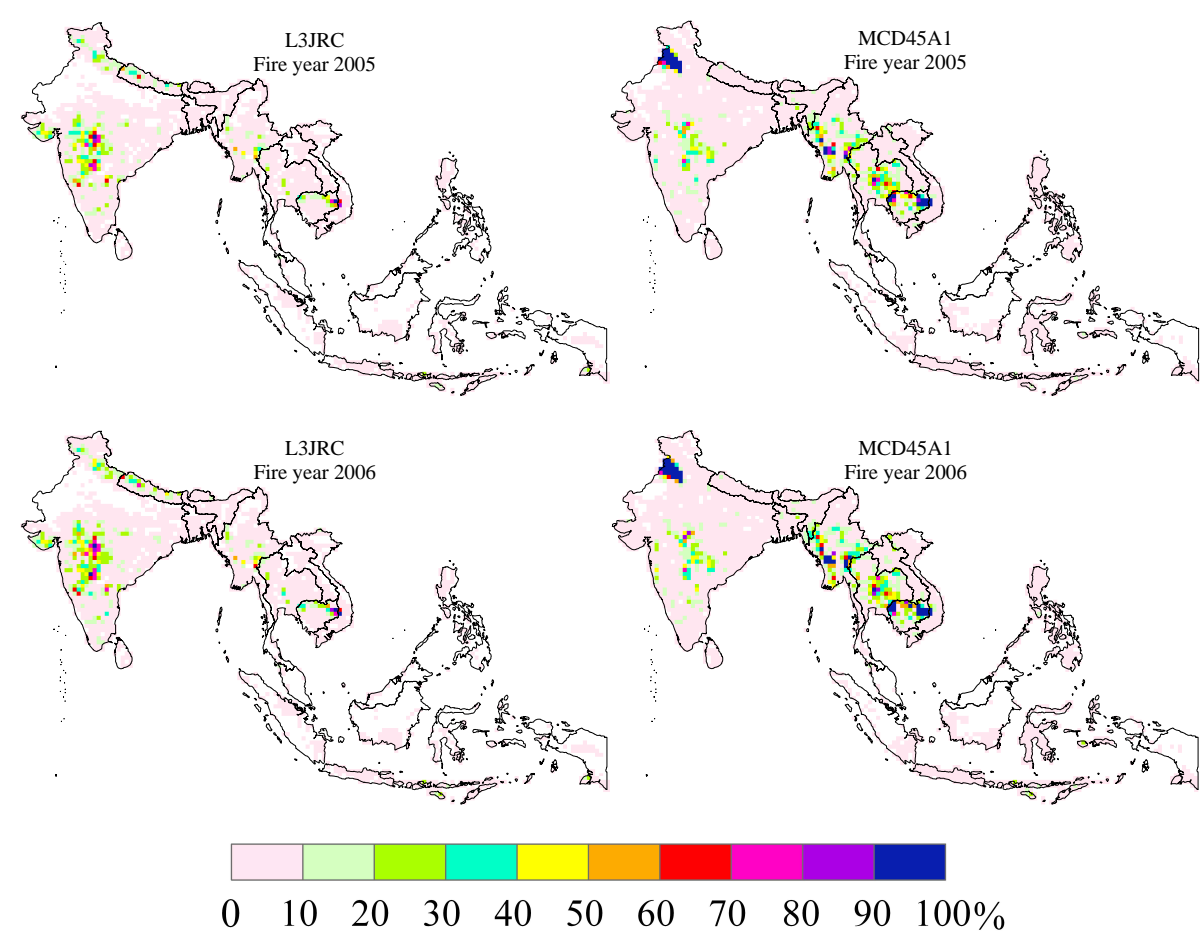

Fig. 2. Continued.

41 years, an average area of $3000 \mathrm{~km}^{2}$ was burned per year within Indonesian peatland between 2000 and 2006 (Heil, 2007). Therefore, the L3JRC and MCD45A1 results may both significantly underestimate the burned peat areas.

According to Fig. 3, the peak month of L3JRC and MCD45A1 burned areas in tropical Asia was observed during February and March. At the country level, the burned areas derived from L3JRC and MCD45A1 in India often peaked between March and May, when India experiences high summer temperatures and dry weather conditions (Kiran Chand et al., 2006). The peak burning month for Myanmar was generally in February or March, whereas Cambodia's peak burning month was in January or February. The peak month of burned area in Thailand generally occurred during January through March, which is the local dry season (www.dnp.go.th/forestfire/Eng/description.htm). Similar temporal patterns of biomass burning in these regions have been found by a number of previous studies (e.g., Duncan et al., 2003; Tansey et al., 2004; Roy et al., 2008). As mentioned above, the sum of the burned areas in these four countries comprised $86 \%$ and $91 \%$ of the total L3JRC and MCD45A1 burned areas in tropical Asia, respectively, and it would seem that the seasonal pattern of biomass burning in tropical Asia was in great part attributable to the temporal distribution of burning in these countries. It is worth noting that the peak month of L3JRC and MCD45A1 burned areas in the Indonesia and Malaysia region was observed during August-October, the Southern Hemisphere dry season (Duncan et al., 2003).
The annual amounts of biomass burned in tropical Asia for the seven fire years are summarized for each vegetation type in Table 3. The amount of biomass burned as calculated from L3JRC ( $\left.74 \mathrm{Tg} \mathrm{yr}^{-1}\right)$ was comparable to that from MCD45A1 (79 $\mathrm{Tg} \mathrm{yr}^{-1}$ ), and they showed similar interannual variation, with a maximum in the fire year 2004 and a minimum in 2000. Of the total biomass burned, $28 \%$ of MCD45A1 was attributed to peat burning, whereas $63 \%$ of L3JRC was from peat land. This difference was probably caused by large burned peat area by L3JRC and high carbon density of SOC $\left(63.65 \mathrm{~kg} \mathrm{C} \mathrm{m}^{-3}\right)$.

\subsection{Comparison of the results from $\mathrm{LBJRC}$ and MCD45A1 with independent reference data}

In order to compare L3JRC and MCD45A1 burned-area data with previous estimates, which have been generally reported by calendar year (i.e., starting from 1 January), all results were converted to calendar years.

\subsubsection{Total burned area in tropical Asia}

First, total L3JRC and MCD45A1 burned-area values for all tropical Asia during calendar years 2001-2006 were compared with the results reported in the Global Fire Emissions Database, Version 2 (GFEDv2.1) (Table 4). The GFEDv2.1 inventory for Asia was produced based on calibrating the MODIS active fire data (van der Werf et al., 2006). The annual L3JRC burned areas ranged from $32713 \mathrm{~km}^{2}$ in 2006 to $62277 \mathrm{~km}^{2}$ in 2001, whereas the annual MCD45A1 burned 
Table 4. Comparison of the total burned areas $\left(\mathrm{km}^{2}\right)$ derived from L3JRC and MCD45A1 products with GFEDv2.1 results during calendar years 2001-2006.

\begin{tabular}{lrrrrrrr}
\hline Calendar year & 2001 & 2002 & 2003 & 2004 & 2005 & 2006 & Average \\
\hline L3JRC $_{\text {MCD45A1 }}^{\text {a }}$ & 62277 & 34188 & 45618 & 48710 & 44097 & 32713 & 44601 \\
GFEDv2.1 $^{6}$ & 103578 & 71427 & 64708 & 126245 & 114779 & 76104 & 86790 \\
\hline
\end{tabular}

a MCD45A1 data for June 2001 are missing.

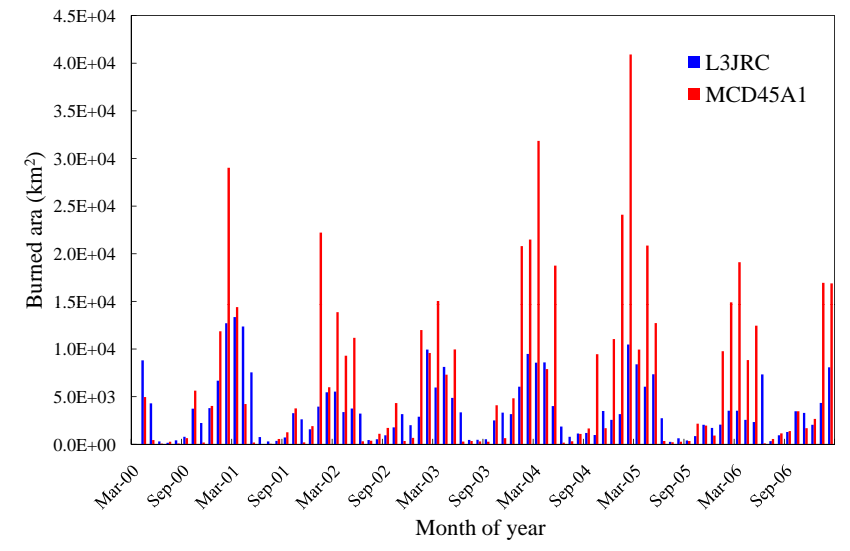

Fig. 3. Monthly L3JRC and MCD45A1 burned areas over seven fire years 2000-2006 in tropical Asia (L3JRC data for March 2000 and MCD45A1 data for March 2000, June 2001 are missing).

areas ranged from $64708 \mathrm{~km}^{2}$ in 2003 to $126245 \mathrm{~km}^{2}$ in 2004. The annual GFEDv2.1 burned areas ranged from $86282 \mathrm{~km}^{2}$ in 2003 to $168904 \mathrm{~km}^{2}$ in 2004 . Accordingly, the MCD45A1 and GFEDv2.1 products' figures were not only comparable, but also showed a similar inter-annual variability, with the minimum burned area in 2003 and the maximum in 2004. This may be because they were both based on the MODIS sensor. In contrast, the L3JRC results were substantially smaller than GFEDv2.1 estimates and exhibited an entirely different interannual change trend.

Figure 4 shows the correlation between the monthly burned areas derived in this study (i.e., L3JRC and MCD45A1 burned areas) and the GFEDv2.1 burned areas for 17 countries in tropical Asia from April 2000 to December 2006. The linear regression equation and the coefficient of determination $\left(R^{2}\right)$ for L3JRC and MCD45A1 are reported. It is noted that the intercept was not included in the regression equation. The regression line slope for MCD45A1 was 0.516 , the $R$-squared value was 0.392 , and the slope and the $R$-squared value for L3JRC were 0.187 and 0.191 , respectively. This meant that MCD45A1 was only moderately correlated with GFEDv2.1, with significant underestimation, and no clear relationship was observed between L3JRC and GFEDv2.1 burned areas.

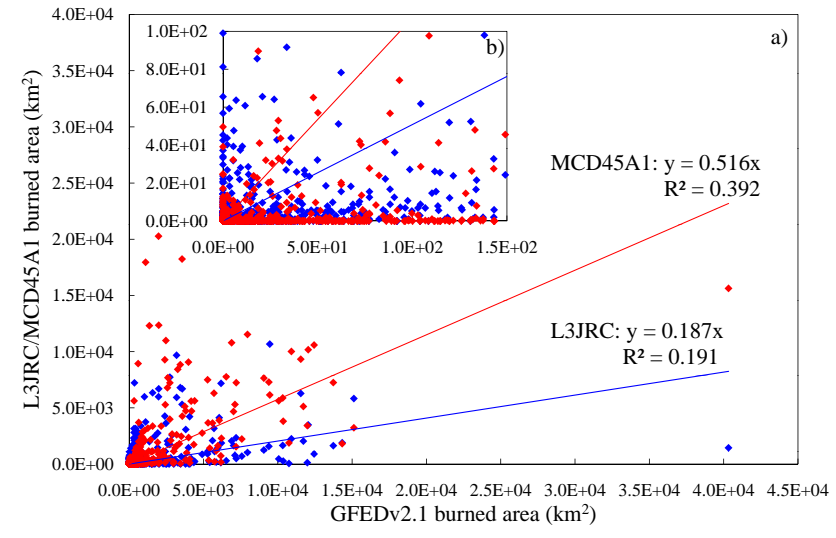

Fig. 4. Scatter plots of the monthly satellite-derived burned areas. (a) L3JRC (blue) and MCD45A1 (red), and GFEDv2.1 estimates in tropical Asia from April 2000 to December 2006. Small burned areas are shown in detail in (b). The intercept is not included in the regression equation.

\subsubsection{India}

The L3JRC and MCD45A1 burned areas in India for the years 2001 to 2006 are compared with the GFEDv2.1 results in Fig. 5a. The results from L3JRC and GFEDv2.1 are comparable in 2002 and 2006, whereas in the other years, L3JRC showed greater burned areas than GFEDv2.1, with the differences ranging from $11500 \mathrm{~km}^{2}$ in 2005 to $18182 \mathrm{~km}^{2}$ in 2000. The MCD45A1 burned areas for 2001 were similar to those of GFEDv2.1, but MCD45A1 reported significantly larger burned areas in other years, with the differences ranging between $4271 \mathrm{~km}^{2}$ in 2002 and $41199 \mathrm{~km}^{2}$ in 2005 .

Vadrevu et al. (2008) used the ATSR fire count product to characterize the spatial distribution of wildland fires in India from February to June 2006. Although the fire counts cannot determine the actual burned area, they can be used to identify the spatiotemporal pattern of vegetation fires (Vadrevu et al., 2008). The contribution of each state to the total L3JRC and MCD45A1 burned areas in India was evaluated over the period from February to June 2006 and then compared with the contribution of each state to the total ATSR fire counts for the same period (Fig. 5b). As shown, all of the three products reported significant burning in Madhya Pradesh, Maharastra, Andhra Pradesh, and Karnataka. 

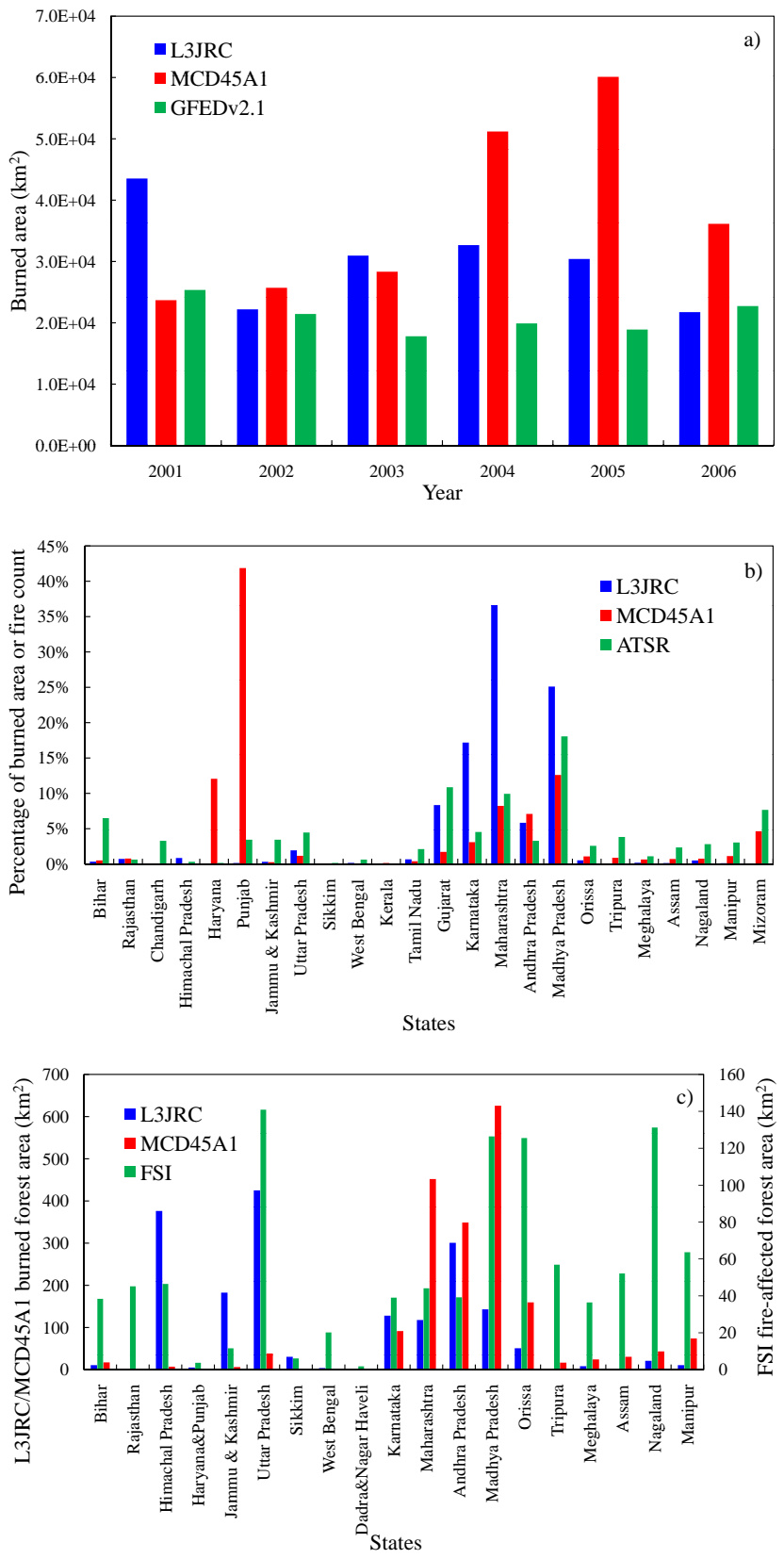

Fig. 5. (a) Comparison of total burned areas $\left(\mathrm{km}^{2}\right)$ derived from L3JRC and MCD45A1 products in India with GFEDv2.1 during 2001-2006. (b) Comparison of the contribution of each state with the total L3JRC and MCD45A1 burned areas and with the total ATSR fire counts over February-June 2006. (c) Comparison of the burned forest areas in each state derived from L3JRC and MCD45A1 with FSI statistics (Bahuguna and Singh, 2002), respectively.

It is noted that in comparison with L3JRC and ATSR, MCD45A1 showed significant burning activity in Punjab and Haryana (Figs. 2, 5b). As an agriculturally important state dominated by rice and wheat in Indo-Gangetic Plains, large sections of Punjab State are completely burned after the harvest season each year (Biopact team, 2008). Based on Indian Remote Sensing Satellite (IRS-P6) Advanced Wide Field Sensor (AWiFS) data, it is estimated that the size of the agricultural area burned in Punjab during May and October 2005 was 5504 and $12685 \mathrm{~km}^{2}$ respectively (Badarinath et al., 2006). This study calculated that the MCD45A1 and L3JRC agricultural burned areas in Punjab for May 2005 were 9509 and $0.84 \mathrm{~km}^{2}$, respectively. In October 2005, MCD45A1 reported an area of $1486 \mathrm{~km}^{2}$ burned in cropland and L3JRC did not detect the burning activity. This shows that the MCD45A1 data were much more comparable to the AWiFS data than were those from L3JRC.

Ground studies of open fires in India have been limited by political intervention and practical difficulties, so existing statistical data tend to be small in scale. National statistics estimated that approximately $14500-37300 \mathrm{~km}^{2}$ of Indian forest were affected by fires annually (Bahuguna and Singh, 2002). Since its inception, the Forest Survey of India (FSI) has reported the extent of forest fires for 19 states. In order to compare the spatial distribution of Indian forest fires with FSI statistics, we calculated the mean areas of forest burned each year using L3JRC and MCD45A1 for each state for the calendar years between 2001 and 2006 (Fig. 5c). MCD45A1 and L3JRC both performed well in the regions that experienced extensive forest fires, e.g., Madhya Pradesh, Maharashtra, Andhra Pradesh, and Orissa. Elsewhere, MCD45A1 reported significantly more burned forest areas than did L3JRC. In other regions with significant burning, i.e., Uttar Pradesh, Himachal Pradesh, and Rajasthan, the MCD45A1 product missed a large number of forest fires. This is probably due to persistent cloud cover during the burning season, which leads to insufficient cloud-free data to derive the burned-area algorithm (Roy et al., 2008). Furthermore, the L3JRC product was originally developed for use on boreal forest, which may explain its better performance in the forested regions (Tansey et al., 2008).

\subsubsection{Indonesia}

The areas of burned land determined by L3JRC and MCD45A1 in Indonesia for 2001-2006 were compared with the results developed from GFEDv2.1 data (see Table 5). The mean burned areas per year from L3JRC and MCD45A1 were 1795 and $2244 \mathrm{~km}^{2}$, respectively. The corresponding GFEDv2.1 result, with an average of $20717 \mathrm{~km}^{2} \mathrm{yr}^{-1}$, was 12 times higher than that from L3JRC and 9 times higher than that from MCD45A1. Similar inter-annual variability was shown by L3JRC and MCD45A1, with the two years of extensive burning (2002 and 2006) caused by EI Niño conditions (Langner and Siegert, 2009). However, in addition to the increased burning detected in 2002 and 2006, GFEDv2.1 showed significant burning activity in 2005, which, according to the ATSR fire count data, was the least extensive fire year between 2001 and 2006 (Langner and Siegert, 2009). Therefore, on some occasions 
Table 5. Comparison of total burned areas $\left(\mathrm{km}^{2}\right)$ derived from L3JRC and MCD45A1 products in Indonesia with GFEDv2.1 results during 2001-2006.

\begin{tabular}{lrrrrrrr}
\hline Calendar year & 2001 & 2002 & 2003 & 2004 & 2005 & 2006 & Average \\
\hline L3JRC & 1084 & 2526 & 1281 & 2285 & 1182 & 2410 & 1795 \\
MCD45A1 $^{\text {a }}$ & 809 & 4455 & 1220 & 2337 & 1012 & 3632 & 2244 \\
GFEDv2.1 $^{4}$ & 4617 & 24180 & 9410 & 19348 & 24449 & 42300 & 20717 \\
\hline
\end{tabular}

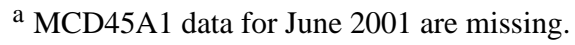

Table 6. Comparison of total burned areas and burned forest areas $\left(\mathrm{km}^{2}\right)$ derived from L3JRC and MCD45A1 products in Thailand with other estimates during 2001-2006 ${ }^{\mathrm{a}}$.

\begin{tabular}{lrrrrrrr}
\hline Calendar year & 2001 & 2002 & 2003 & 2004 & 2005 & 2006 & Average \\
\hline \multicolumn{7}{c}{ Total burned area } \\
\hline L3JRC & 2045 & 479 & 1579 & 1324 & 1619 & 863 & 1318 \\
MCD45A1 & 13825 & 11201 & 7826 & 16412 & 14676 & 6099 & 11673 \\
GFEDv2.1 & 14093 & 15744 & 11313 & 25957 & 22124 & 11062 & 16259 \\
\hline \multicolumn{7}{c}{ Burned forest area } \\
\hline L3JRC & 125 & 41 & 82 & 157 & 199 & 58 & 110 \\
MCD45A1 & 725 & 680 & 221 & 1377 & 928 & 408 & 723 \\
Statistics & 762 & 1394 & 158 & 323 & 303 & 86 & 504 \\
\hline
\end{tabular}

${ }^{\mathrm{a} M C D} 45 \mathrm{~A} 1$ data for June 2001 are missing.

${ }^{\mathrm{b}}$ From Forest Fire Control Division (FFCD), Thailand, available at: http://www.dnp.go.th/ForestFire/Eng/fire\%20statistic.htm.

Table 7. Comparison of total burned areas and burned forest areas $\left(\mathrm{km}^{2}\right)$ derived from L3JRC and MCD45A1 products in Bhutan with other estimates during 2001-2006 ${ }^{\mathrm{a}}$.

\begin{tabular}{lrrrrrrr}
\hline Calendar year & 2001 & 2002 & 2003 & 2004 & 2005 & 2006 & Average \\
\hline \multicolumn{7}{c}{ Total burned area } \\
\hline L3JRC & 483 & 339 & 174 & 246 & 256 & 299 & 300 \\
MCD45A1 & 37 & 25 & 7 & 16 & 8 & 38 & 22 \\
GFEDv2.1 & 188 & 88 & 23 & 35 & 36 & 122 & 82 \\
\hline \multicolumn{7}{c}{ Burned forest area } \\
\hline L3JRC & 310 & 229 & 122 & 163 & 156 & 204 & 197 \\
MCD45A1 & 18 & 18 & 5.6 & 8.5 & 4.2 & 23 & 13 \\
Statistics & 233 & 146 & 57 & 26 & - & - & 116 \\
\hline
\end{tabular}

a MCD45A1 data for June 2001 are missing.

${ }^{\mathrm{b}}$ From International Forest Fire News (Dorji, 2006).

the GFEDv2.1 may overestimate the burned area in Indonesia. The RETRO biomass-burning inventory showed that an average of $10000 \mathrm{~km}^{2}$ was burned annually in Indonesia between 2000 and 2006 (Heil, 2007). Therefore, both L3JRC and MCD45A1 products may have significantly underestimated the burned area in the equatorial zone and may need further evaluation with reliable ground observations.

\subsubsection{Thailand}

The total burned areas in Thailand derived from L3JRC and MCD45A1 products were compared with the results from GFEDv2.1 for the interval 2001-2006 (Table 6). The total annual area burned, as shown by L3JRC, ranged between $479 \mathrm{~km}^{2}$ in 2002 and $2045 \mathrm{~km}^{2}$ in 2001. This is lower than the estimates from GFEDv2.1, which range from $11062 \mathrm{~km}^{2}$ in 2006 to $25957 \mathrm{~km}^{2}$ in 2004, by a factor of seven to 33 . 
Table 8. Summary of fire emissions (Tg) in tropical Asia during fire years from 2000-2006.

\begin{tabular}{lrrrllllllll}
\hline Species & $\mathrm{CO}_{2}$ & $\mathrm{CO}$ & $\mathrm{CH}_{4}$ & $\mathrm{NMHC}_{\mathrm{s}}$ & $\mathrm{NO}_{\mathrm{x}}$ & $\mathrm{NH}_{3}$ & $\mathrm{SO}_{2}$ & $\mathrm{BC}$ & $\mathrm{OC}$ & $\mathrm{PM}_{2.5}$ & $\mathrm{PM}_{10}$ \\
\hline \multicolumn{10}{c}{$\mathrm{L3JRC}$} \\
\hline 2000 & 68 & 5 & 0.3 & 0.5 & 0.07 & 0.2 & 0.02 & 0.020 & 0.2 & 1.4 & 1.6 \\
2001 & 96 & 8 & 0.6 & 1.1 & 0.10 & 0.5 & 0.03 & 0.022 & 0.3 & 2.2 & 2.4 \\
2002 & 169 & 18 & 1.6 & 3.2 & 0.13 & 1.5 & 0.06 & 0.020 & 0.6 & 5.1 & 5.5 \\
2003 & 97 & 8 & 0.6 & 1.2 & 0.09 & 0.6 & 0.03 & 0.022 & 0.3 & 2.4 & 2.6 \\
2004 & 175 & 18 & 1.5 & 3.0 & 0.14 & 1.4 & 0.06 & 0.024 & 0.6 & 5.2 & 5.6 \\
2005 & 117 & 11 & 1.0 & 1.9 & 0.10 & 0.9 & 0.04 & 0.018 & 0.4 & 3.3 & 3.5 \\
2006 & 138 & 14 & 1.2 & 2.3 & 0.11 & 1.1 & 0.05 & 0.021 & 0.5 & 3.9 & 4.3 \\
\hline & & & \multicolumn{10}{c}{ MCD45A1 } & & & & & \\
\hline 2000 & 66 & 4 & 0.2 & 0.2 & 0.07 & 0.1 & 0.02 & 0.024 & 0.21 & 1.4 & 1.6 \\
2001 & 77 & 5 & 0.3 & 0.5 & 0.08 & 0.3 & 0.03 & 0.024 & 0.24 & 1.6 & 1.8 \\
2002 & 189 & 19 & 1.6 & 3.2 & 0.14 & 1.5 & 0.07 & 0.029 & 0.64 & 5.7 & 6.1 \\
2003 & 104 & 6 & 0.3 & 0.5 & 0.10 & 0.2 & 0.04 & 0.037 & 0.33 & 2.3 & 2.5 \\
2004 & 210 & 16 & 1.0 & 1.7 & 0.19 & 0.8 & 0.08 & 0.060 & 0.66 & 5.2 & 5.6 \\
2005 & 69 & 4 & 0.2 & 0.4 & 0.07 & 0.2 & 0.02 & 0.023 & 0.21 & 1.5 & 1.6 \\
2006 & 139 & 11 & 0.8 & 1.4 & 0.13 & 0.7 & 0.05 & 0.036 & 0.45 & 3.5 & 3.8 \\
\hline
\end{tabular}

The MCD45A1 burned areas ranged from $6099 \mathrm{~km}^{2}$ in 2006 and $16412 \mathrm{~km}^{2}$ in 2004 and compared reasonably well to the GFEDv2.1 results. According to the data from Global Vegetation Fire Inventory (GVFI), about $13661 \mathrm{~km}^{2}$ of land were burnt in Thailand in 2002, and the average area burned annually in Thailand was $13661 \mathrm{~km}^{2}$ (available from http: //www.fire.uni-freiburg.de/inventory/gvfi.htm). Compared these data to our results in Table 6, MCD45A1 was in a good agreement with GVFI, and L3JRC presented large underestimation.

A comparison of the burned forest areas in Thailand derived from L3JRC and MCD45A1 with the statistical data obtained from Forest Fire Control Division (FFCD) is shown in Table 6. The FFCD data were collected from 120 forest fire control stations in Thailand, which cover $21 \%$ of the national forest area (P. Nhuchaiya, Forest Fire Control Division, personal communication, 2010). This information could be the lower limit of the fire-affected area. Accordingly, comparison in Table 6 illustrated that there was a significant underestimation of burned area for L3JRC.

\subsubsection{Bhutan}

The total burned area in Bhutan as calculated in this study was compared with the results from GFEDv2.1 and the total burned forest areas compared with the statistical data compiled by IFFN (Dorji, 2006) (Table 7). The annual mean L3JRC burned area was $300 \mathrm{~km}^{2} \mathrm{yr}^{-1}$, significantly greater than the annual GFEDv2.1 estimate of $82 \mathrm{~km}^{2} \mathrm{yr}^{-1}$, whereas the MCD45A1 burned area was $22 \mathrm{~km}^{2} \mathrm{yr}^{-1}, 60 \mathrm{~km}^{2} \mathrm{yr}^{-1}$ lower than the results from GFEDv2.1. However, IFFN showed that the extent of forest fires in Bhutan for the years
2001, 2002, 2003 and 2004 were 233, 146, 57, and $26 \mathrm{~km}^{2}$, respectively (Dorji, 2006), greater than the total burned areas calculated from GFEDv2.1 data, with the exception of the year 2004. This implies that the GFEDv2.1 and MCD45A1 results underestimated the extent of the burned areas in Bhutan. The burned forest areas derived from L3JRC were in accordance with the IFFN data, whereas the MCD45A1 was significantly lower than the IFFN statistics. These figures include a forest fire that occurred in the Wangdue district during 2006-2007 and burnt approximately $150 \mathrm{~km}^{2}$ of land alone (Dorji, 2006). The burned forest area in 2006 derived from L3JRC was $204 \mathrm{~km}^{2}$, but was $23 \mathrm{~km}^{2}$ from MCD45A1. As a consequence, the L3JRC results for Bhutan are more comparable to the statistical data than are those from MCD45A1, which showed a significant underestimation, especially within forested regions.

\subsection{Fire emissions}

The total emissions from open biomass burning for each species $\left(\mathrm{CO}_{2}, \mathrm{CO}, \mathrm{CH}_{4}, \mathrm{NMHC}_{\mathrm{s}}, \mathrm{NO}_{\mathrm{x}}, \mathrm{NH}_{3}, \mathrm{SO}_{2}, \mathrm{BC}, \mathrm{OC}\right.$, $\mathrm{PM}_{2.5}$, and $\mathrm{PM}_{10}$ ) during the seven fire years from 2000 to 2006 derived from the L3JRC and MCD45A1 products are presented in Table 8. As shown, the L3JRC-based fire emissions were comparable to, and even somewhat larger than, those from MCD45A1. This should perhaps have been expected considering that the estimations of burned biomass made by L3JRC and MCD45A1 were comparable. Taking $\mathrm{CO}$ as an example, of the total L3JRC-derived emission of $12 \mathrm{Tg} \mathrm{CO} \mathrm{yr}^{-1}, 8 \mathrm{Tg}(72 \%)$ was from peat burning, whereas $4 \mathrm{Tg}(28 \%)$ was from aboveground vegetation fires. The total MCD45A1-based emission was $9 \mathrm{Tg} \mathrm{CO} \mathrm{yr}^{-1}$, of which $4 \mathrm{Tg}$ 
Table 9. Summary of annual emissions $\left(\mathrm{Tg} \mathrm{yr}^{-1}\right)$ for seven major species for each vegetation type over seven fire years from $2000-2006$.

\begin{tabular}{lccccccc}
\hline Species & $\mathrm{CO}_{2}$ & $\mathrm{CO}$ & $\mathrm{NMHC}_{\mathrm{s}}$ & $\mathrm{NO}_{\mathrm{x}}$ & $\mathrm{SO}_{2}$ & $\mathrm{PM}_{2.5}$ & $\mathrm{PM}_{10}$ \\
\hline \multicolumn{7}{c}{$\mathrm{L} 3 \mathrm{JRC}$} \\
\hline Forest & 58 & 5.9 & 1.06 & 0.05 & 0.02 & 1.7 & 1.8 \\
Shrubland & 18 & 2.0 & 0.35 & 0.01 & 0.01 & 0.6 & 0.6 \\
Grassland & 12 & 0.7 & 0.05 & 0.01 & 0.00 & 0.3 & 0.3 \\
Cropland & 34 & 2.9 & 0.43 & 0.03 & 0.01 & 0.9 & 0.9 \\
\hline \multicolumn{7}{c}{$\mathrm{MCD} 45 \mathrm{~A} 1$} \\
\hline Forest & 41 & 3.4 & 0.44 & 0.04 & 0.01 & 1.2 & 1.3 \\
Shrubland & 22 & 1.9 & 0.21 & 0.02 & 0.01 & 0.5 & 0.6 \\
Grassland & 17 & 1.1 & 0.07 & 0.02 & 0.01 & 0.4 & 0.5 \\
Cropland & 41 & 3.0 & 0.39 & 0.04 & 0.01 & 0.9 & 1.0 \\
\hline
\end{tabular}

(42\%) was caused by peat burning, and $5 \mathrm{Tg}(58 \%)$ was due to aboveground vegetation fires. The higher percentage of burning activity in peatland areas detected by L3JRC compared with that shown by MCD45A1 may explain the contrast between the emissions derived from L3JRC and from MCD45A1.

Compared with the spatial distribution of the burned areas, fire emissions from tropical Asia presented a different pattern. Indonesia was shown to be the most significant contributor to the emissions, followed by India, Myanmar, and Cambodia, in order of decreasing magnitude. Using $\mathrm{CO}$ as an illustrative example, the L3JRC-derived emissions in Indonesia, India, Myanmar, and Cambodia accounted for approximately $73 \%, 13 \%, 3.5 \%$, and $3.0 \%$ of the total emissions, respectively, whereas the corresponding MCD45A1derived emissions for these four countries were $44 \%, 14 \%$, $16 \%$, and $11 \%$, respectively. It is worth noting that, of the total Indonesian emissions of $8.5 \mathrm{Tg} \mathrm{CO} \mathrm{yr}^{-1}$ for L3JRC and 4.1 $\mathrm{Tg} \mathrm{CO} \mathrm{yr}^{-1}$ for MCD45A1, peat burning made the major contribution (97\% for L3JRC and 95\% for MCD45A1). This highlights the importance of organic carbon in soil with respect to biomass burning in equatorial Asia (Page et al., 2002).

The average annual emissions for the major species within forest, shrubland, grassland, and cropland are listed in Table 9. On the whole, forest was the largest contributor to fire emissions, representing a large carbon pool, followed by cropland, shrubland, and, finally, grassland. However, the emissions from crop residue combustion in tropical Asia may be greatly underestimated due to the fact that the agricultural fuel loading has been estimated to be $4-5 \mathrm{~kg} \mathrm{~m}^{-2}$ (Levine, 1999; Heil, 2007), whereas the mean available fuel load used in this study was $0.13 \mathrm{~kg} \mathrm{~m}^{-2}$. This difference may be due to the fact that only the field crop residue was taken into account in our study as most agricultural burning in Asia occurs after the harvest season, when most farmers burn off the crop residue to get rid of it. The agricultural fu- els in Levine (1999) included the biomass in plantation areas (mainly rubber trees and oil palms), and the agricultural fuel loading in Heil (2007) contained many other nonagricultural fuels in grassland and savannah. The biomass density for these fuels is higher than that for crop residue.

Inventories of emissions from biomass burning for all of Asia during the mid-1990s have been established in support of the ACE-Asia and Trace-P campaigns (Streets et al., 2003). The emission estimates from agricultural and non-agricultural burning in tropical Asia calculated in this study are compared with the emission inventory of Streets et al. (2003) in Table 10. As shown, their results were 116 times higher than estimates in this study. This significant difference was mostly caused by the distinct burning data used in estimating fire emissions. The emission inventories for forest and savannah burning in tropical Asia were based on burning data from the 1950s to the 1990s, which were representative of local burning information during mid-1970s and significantly higher than the results from recent studies (e.g., Ito and Penner, 2004). It is estimated that burning activities have changed drastically over the last three decades (Streets et al., 2003), and consequently, the discrepancy between their results and the estimates made in this study were to be expected. The emissions from agricultural residue combustion in Streets et al. (2003) were also substantially higher than the estimates made in this study. This may be because their data on the amount of combusted crop residue were from the FAO statistics, which were significantly larger than those derived from the satellite-based data used in this study. The GFEDv2.1 results showed that the total $\mathrm{CO}$ emissions from tropical Asian biomass burning were $248,441,754,350,744,745$, and $1116 \mathrm{Tg}$ for the calendar years 2000 to 2006, respectively (van der Werf et al., 2006), which are 54 times higher than L3JRC-derived CO emissions and 64 times higher than MCD45A1-derived CO emissions. Hoelzemann et al. (2004) calculated that $18.7 \mathrm{Tg}$ of $\mathrm{CO}$ and $0.42 \mathrm{Tg}$ of $\mathrm{NO}_{\mathrm{x}}$ were released through biomass 
Table 10. Comparison of the fire emissions $\left(\mathrm{Tg} \mathrm{yr}^{-1}\right)$ calculated in our study with other published estimates in tropical Asia.

\begin{tabular}{lrrrrrrrr}
\hline Species & $\mathrm{CO}_{2}$ & $\mathrm{CO}$ & $\mathrm{CH}_{4}$ & $\mathrm{NMHC}_{\mathrm{S}}$ & $\mathrm{NH}_{3}$ & $\mathrm{SO}_{2}$ & $\mathrm{BC}$ & $\mathrm{OC}$ \\
\hline \multicolumn{7}{c}{ Forest/Shrub/Grassland burning } \\
\hline L3JRC & 88 & 8.6 & 0.74 & 1.47 & 0.68 & 0.031 & 0.014 & 0.31 \\
MCD45A1 & 81 & 6.3 & 0.43 & 0.73 & 0.36 & 0.029 & 0.021 & 0.26 \\
Streets et al. (2003) & 573 & 35 & 2.06 & 6.44 & 0.46 & 0.21 & 0.22 & 1.93 \\
\hline \multicolumn{7}{c}{ Crop residue burning } \\
\hline L3JRC & 34 & 2.9 & 0.23 & 0.43 & 0.21 & 0.01 & 0.01 & 0.11 \\
MCD45A1 & 41 & 3.0 & 0.20 & 0.39 & 0.18 & 0.01 & 0.01 & 0.13 \\
Streets et al. (2003) & 197 & 12 & 0.35 & 2.0 & 0.17 & 0.05 & 0.09 & 0.43 \\
\hline
\end{tabular}

a From Center for Global and Regional Environmental Research, available at: http://www.cgrer.uiowa.edu/EMISSION_DATA_new/.

burning in Southern Asia during calendar year 2000. However, the $\mathrm{CO}$ and $\mathrm{NO}_{\mathrm{x}}$ emissions derived from L3JRC for fire year 2000 were 5 and $0.07 \mathrm{Tg}$, respectively, and 4 and 0.07 Tg for MCD45A1. Both L3JRC- and MCD45A1-based emission estimates were significantly lower than those in previous studies. A comparison of the data used in calculating fire emissions suggested that the available fuel load values in this study, especially for forested regions, were smaller than those used in Hoelzemann et al. (2004) and van der Werf et al. (2006). The biomass density data used in this study were taken from previous studies, but the biomass density data in Hoelzemann et al. (2004) and van der Werf et al. (2006) were predicted from ecological models. Besides, the literature data used in our study only assessed the biomass density for trees above a certain diameter (Brown et al., 1993; Brown, 1997) and consequently excluded most fire-susceptible parts of the vegetation (Hoelzemann et al., 2004).

The monthly variations in $\mathrm{CO}$ emissions derived from the L3JRC and MCD45A1 burned-area products from March 2000 to February 2007 are shown in Fig. 6. Generally, two peaks in $\mathrm{CO}$ emissions were observed, one during February and March, and another during August-October. The first peak was attributed to aboveground vegetation fires, whereas the second was attributed to SOC burning. As mentioned in Sect. 3.1, the peak in burned areas often occurred in February and March and, accordingly, the seasonal distribution of emissions from overlying biomass combustion was consistent with that of burned areas. As most peat combustion in Indonesia and Malaysia generally occurred during extensive fire activity between August and October, the fact that maximum CO emissions from peat burning also occurred in the late fire season was to be expected. Heil (2007) also stated that the contribution of peat combustion to Indonesian $\mathrm{CO}$ emissions tended to rise when enhanced fire activities occurred during the late burning season owing to the intensification and prolongation of drought conditions.

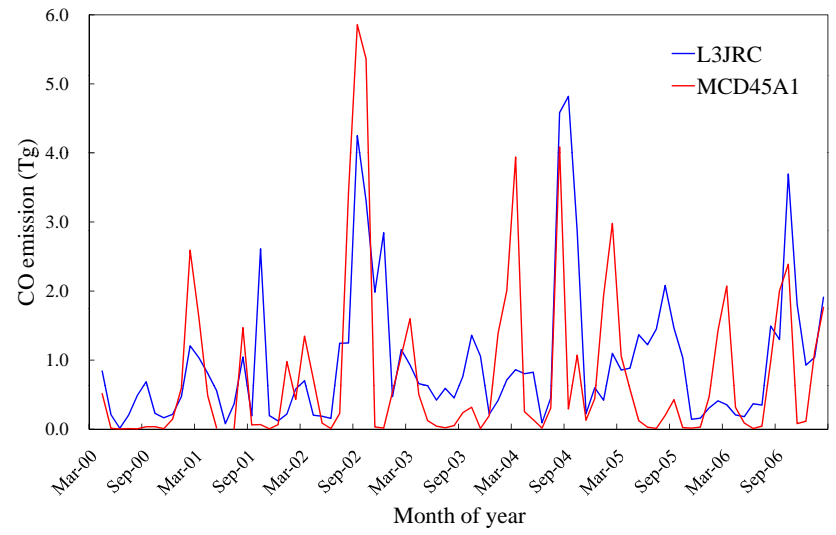

Fig. 6. Temporal distribution in $\mathrm{CO}$ emissions derived from L3JRC and MCD45A1 during fire years 2000-2006.

\subsection{Emission uncertainties}

The uncertainty associated with the emission figures results from the uncertainties surrounding the size of the burned area, fuel load, CF, and EF. Comparison of L3JRC and MCD45A1 data with reference data suggested MCD45A1 generally performed better than L3JRC, but underestimated the burning in forest. It is difficult to assess the uncertainty of the satellite-derived data for area of burned land (Hoelzemann et al., 2004), and the combustion factor was estimated from empirical formulae. Thus, the uncertainties in this study were mainly caused by fuel load and emission factor. We assumed that the fuel load obeyed a Gaussian normal distribution with a standard deviation of $50 \%$ of the mean value. Typically, the uncertainty surrounding the emission factor was in the order of 20-30\% (Hoelzemann et al., 2004). Within this study, 20000 Monte Carlo simulations were performed to try to estimate the range of fire emissions with a $90 \%$ confidence interval and the results are presented in Table 11. 
Table 11. Summary of the emission ranges $\left(\mathrm{Tg} \mathrm{yr}^{-1}\right)$ for each species (90\% confidence interval).

\begin{tabular}{lrr}
\hline Species & L3JRC & MCD45A1 \\
\hline $\mathrm{CO}_{2}$ & $102-152$ & $108-144$ \\
$\mathrm{CO}$ & $9-15$ & $7.7-11.7$ \\
$\mathrm{CH}_{4}$ & $0.7-1.3$ & $0.46-0.86$ \\
$\mathrm{NMHC}_{\mathrm{S}}$ & $1.4-2.6$ & $0.8-1.6$ \\
$\mathrm{NO}_{\mathrm{x}}$ & $0.09-0.12$ & $0.10-0.13$ \\
$\mathrm{NH}_{3}$ & $0.63-1.21$ & $0.38-0.76$ \\
$\mathrm{SO}_{2}$ & $0.036-0.053$ & $0.038-0.051$ \\
$\mathrm{BC}$ & $0.021-0.023$ & $0.032-0.037$ \\
$\mathrm{OC}$ & $0.34-0.52$ & $0.34-0.47$ \\
$\mathrm{PM}_{2.5}$ & $2.6-4.3$ & $2.6-3.7$ \\
$\mathrm{PM}_{10}$ & $2.8-4.7$ & $2.8-4.0$ \\
\hline
\end{tabular}

\section{Conclusions}

In this study, emissions from open biomass burning in tropical Asia were estimated for seven fire years from 2000 to 2006, taking advantage of recently released satellite products: the 1-km L3JRC burned-area product and 500-m MODIS product (MCD45A1). Throughout this period, the average annual L3JRC-derived data for total area burned was $43514 \mathrm{~km}^{2} \mathrm{yr}^{-1}$, and the average annual MCD45A1 burned area was $85277 \mathrm{~km}^{2} \mathrm{yr}^{-1}$. For the two satellite products, the burned areas were predominantly concentrated in cropland, followed by forest, grassland, and then shrubland. This study compared the burned areas derived from the two products with previously published fire data for India, Indonesia, Thailand, Bhutan, and for the whole of tropical Asia. Validation results suggested that the MCD45A1 product was generally better than L3JRC with the under-detection in forested region. The average annual L3JRC-based $\mathrm{CO}_{2}, \mathrm{CO}, \mathrm{CH}_{4}$, $\mathrm{NO}_{\mathrm{x}}, \mathrm{BC}, \mathrm{OC}$, and $\mathrm{PM}_{2.5}$ emissions were 123 (102-152), 12 (9-15), 1.0 (0.7-1.3), 0.11 (0.09-0.12), 0.021 (0.021$0.023), 0.41(0.34-0.52)$, and $3.4(2.6-4.3) \mathrm{Tg} \mathrm{yr}^{-1}$, respectively, whereas the average annual MCD45A1-based emissions were 122 (108-144), 9.3 (7.7-11.7), 0.63 (0.46-0.86), $0.11(0.10-0.13), 0.033$ (0.032-0.037), 0.39 (0.34-0.47), and 3.0 (2.6-3.7) $\mathrm{Tg} \mathrm{yr}^{-1}$. Indonesia, India, Myanmar, and Cambodia were the main contributors to fire emissions. In addition, the majority of fire emissions were attributed to forest fires, followed by cropland, shrubland, and grassland fires. Nevertheless, the influence of agricultural burning may have been significantly underestimated due to the difficulty of detecting small-sized fires by satellite sensors. The peak month for area burned, according to the L3JRC and MCD45A1 products, was typically in February-March, whereas two peaks in fire emissions were observed: one during FebruaryMarch associated with aboveground vegetation burning, and another during August-October caused by peat combustion.
Acknowledgements. The L3JRC and MCD45A1 burned area products are provided by the Joint Research Centre (JRC), European Commission, and the University of Maryland, respectively. The MODIS NDVI, VCF products are provided by the Land Process Distributed Active Archive Center (LPDAAC), USA. The GlobCover product was developed by ESA GlobCover Project, led by MEDIAS-France. This study was funded by the Public Welfare Projects for Environmental Protection (200809018, 200709001), the National Key Basic Research and Development Program of China (2006AA06A306), European Commission FP-7 CITYZEN (212095), and the New-Century Training Program Foundation for Talents from the Ministry of Education of China.

Edited by: B. N. Duncan

\section{References}

Andreae, M. O. and Merlet, P.: Emission of trace gases and aerosols from biomass burning, Global Biogeochem. Cy., 15(4), 955-966, 2001.

Badarinath, K. V. S., Kiran Chand, T. R., and Krishna Prasad, V.: Agriculture crop residue burning in the Indo-Gangetic Plains A study using IRS-P6 AWiFS satellite data, Curr. Sci., 91, 10851089, 2006.

Bahuguna, V. K. and Singh, S.: Fire situation in India, Int. Forest Fire News, 26, 23-27, online available at: http://www.fire. uni-freiburg.de/iffn/country/in/in_5.htm, 2002.

Batjes, N. H.: Total carbon and nitrogen in the soils of the world, Eur. J. Soil Sci., 47, 151-163, 1996.

Bicheron, P., Defourny, P., Brockmann, C., Schouten, L., Vancutsem, C., Huc, M., Bontemps, S., Leroy, M., Achard, F., Herold, M., Ranera, F., and Arino, O.: GlobCover: Products Description and Validation Report, 18, avenue E. Belin, bpi 2102, 31401 Toulouse Cedex 9, France, 2008.

Biopact team: A burning issue: satellite data show very large potential of rice straw as bioenergy feedstock, online available at: http://news.mongabay.com/bioenergy/2008/07/ burning-issue-satellite-data-show-very.html, 30 July 2008.

Boehm, H. D. V., Siegert, F., Rieley, J. O., Page, S. E., Jauhiainen, J., Vasander, H., and Jaya, A.: Fire impacts and carbon release on tropical peatlands in Central Kalimantan, Indonesia, paper presented at the $22^{\text {nd }}$ Asian Conference on Remote Sensing, Cent. For Remote Imaging, Sens., and Process., Natl. Univ. of Singapore, Singapore, 2001.

Boschetti, L. and Roy, D.: Defining a fire year for reporting and analysis of global fire inter-annual variability, J. Geophys. Res., 113, G03020, doi:10.1029/2008JG000686, 2008.

Brown, S.: Estimating Biomass and Biomass Change of Tropical Forests, FAO For. Pap. 134, Food and Agric. Org., Rome, 55 pp., 1997.

Brown, S., Iverson, L. R., Prasad, A., and Liu, D.: Geographical distributions of carbon in biomass and soils of tropical Asian forests, Geocarto Int., 4, 45-59, 1993.

Burgan, R. E., Klaver, R. W., and Klaver, J. M.: Fuel models and fire potential from satellite and surface observations, Int. J. Wildland Fire, 8(3), 159-170, 1998.

Chandra, S., Ziemke, J. R., Bhartia, P. K., and Martin, R. V.: Tropical tropospheric ozone: Implications for dynam- 
ics and biomass burning, J. Geophys. Res., 107(D14), 4188, doi:10.1029/2001JD000447, 2002.

Chhabra, A. and Dadhwal, V. K.: Assessment of major pools and fluxes of carbon in Indian forests, Climatic Change, 64, 341-360, 2004.

Christian, T. J., Kleiss, B., Yokelson, R. J., Holzinger, R., Crutzen, P. J., Hao, W. M., Shirai, T., and Blake, D. R.: Comprehensive laboratory measurements of biomass-burning emissions: 1 . Emissions from Indonesian, African, and other fuels, J. Geophys. Res., 108(D23), 4719, doi:10.1029/2003JD003704, 2003.

Crutzen, P. J. and Andreae, M. O.: Biomass burning in the tropics: impact on atmospheric chemistry and biogeochemical cycles, Science, 250, 1669-1678, 1990.

Dorji, T.: Fire Situation in Bhutan, Int. Forest Fire News, 34, 55-63, online available at: http://www.fire.uni-freiburg.de/iffn/iffn_34/ 07-IFFN-34-Bhutan.pdf, 2006.

Duncan, B. N., Martin, R. V., Staudt, A. C., Yevich, R., and Logan, J. A.: Interannual and seasonal variability of biomass burning emissions constrained by satellite observations, J. Geophys. Res.-Atmos., 108, 4100, doi:10.1029/2002JD002378, 2003.

European Space Agency: GLOBCARBON, Demonstration Products and Qualification Report, version 3.1, 161 pp., 2006.

FAO: WRB (World Reference Base) Map of World Soil Resources, Land and Water Development Division AGL, Food and Agriculture Organization of the United Nations, Rome, Italy, online available at: http://www.fao.org/ag/agl/agll/wrb/soilres.stm, (last accesss: 2 January 2004), 2003.

FAO: FAO Statistical Yearbook 2004, Food and Agric. Organ., Rome, 2006.

Ferek, R. J., Reid, J. S., Hobbs, P. V., Blake, D. R., and Liousse, C.: Emission factors of hydrocarbons, halocarbons, trace gases and particles from biomass burning in Brazil, J. Geophys. Res., 103(D24), 32107-32118, 1998.

Hansen, M. C., DeFries, R. S., Townshend, J. R. G., Carroll, M., Dimiceli, C., and Sohlberg, R. A.: Global percent tree cover at a spatial resolution of 500 meters: First results of the MODIS vegetation continuous fields algorithm, Earth Interact., 7, 1-15, 2003.

Hao, W. M. and Liu, M. H.: Spatial and temporal distribution of tropical biomass burning, Global Biogeochem. Cy., 8, 495-503, 1994.

Hao, W. M., Liu, M. H., and Crutzen, P. J.: Estimates of annual and regional releases of $\mathrm{CO}_{2}$ and other trace gases to the atmosphere from fires in the tropics, based on the FAO statistics for the period 1975-1980, in: Fire in the Tropical Biota: Ecosystem Processes and Global Challenges, Ecol. Studies 84, edited by: Goldammer, J. G., Springer-Verlag, New York, 440-462, 1990.

Harmon, M. E. and Hua, C.: Coarse woody debris dynamics in two old-growth, BioScience, 41(9), 604-610, 1991.

Hashimotio, T., Kojima, K., Tange, T., and Sasaki, S.: Changes in carbon storage in fallow forests in the tropical lowlands of Borneo, Forest Ecol. Manag., 126, 331-337, 2000.

Heil, A.: Indonesian forest and peat fires: emissions, air quality, and human health, Ph.D. thesis, Max Planck Inst. for Meteorol., Hamburg, 142 pp., 2007.

Hoelzemann, J. J., Schultz, M. G., Brasseur, G. P., Granier, C., and Simon, M.: Global Wildland Fire Emission Model (GWEM): Evaluating the use of global area burnt satellite data, J. Geophys. Res.-Atmos., 109, D14S04 doi:10.1029/2003JD003666, 2004.
Hoffa, E. A., Ward, D. E., Hao, W. M., Susott, R. A., and Wakimoto, R. H.: Seasonality of carbon emissions from biomass burning in a Zambian savanna, J. Geophys. Res.-Atmos., 104, 1384113853, 1999.

Ito, A., Ito, A., and Akimoto, H.: Seasonal and interannual variations in $\mathrm{CO}$ and $\mathrm{BC}$ emissions from open biomass burning in Southern Africa during 1998-2005, Global Biogeochem. Cy., 21, GB2011, doi:10.1029/2006GB002848, 2007.

Ito, A. and Penner, J. E.: Global estimates of biomass burning emissions based on satellite imagery for the year 2000, J. Geophys Res. Atmos., 109, D14S05, doi:10.1029/2003JD004423, 2004.

Ito, A. and Penner, J. E.: Estimates of CO emissions form open biomass burning in southern Africa for the year 2000, J. Geophys. Res., 110, D19306, doi:10.1029/2004JD005347, 2005.

Kasischke, E. S. and Penner, J. E.: Improving global estimates of atmospheric emissions from biomass burning, J. Geophys. Res.Atmos., 109, D14S01, doi:10.1029/2004JD004972, 2004.

Kiran Chand, T. R., Badarinath, K. V. S., Krishna Prasad, V., Murthy, M. S. R., Elvidge, C. D., and Tuttle, B. T.: Monitoring forest fires over the Indian region using defense meteorological satellite program-operational Linescan system nighttime satellite data, Remote Sens. Environ., 103(2), 165-178, 2006.

Kogan, F. N.: Global drought watch from space, B. Am. Meteorol. Soc., 78(4), 621-636, 1997.

Koopmans, A. and Koppejan, J.: Agricultural and Forest Residues: Generation, Utilization and Availability, Paper presented at the Regional Consultation on Modern Applications of Biomass Energy, FAO, Kuala Lumpur, Malaysia, 1997.

Korontzi, S.: Seasonal patterns in biomass burning emissions from southern African vegetation fires for the year 2000, Global Change Biol., 11, 1680-1700, doi:10.1111/j.13652486.2005.01024.x, 2005.

Langner, A. and Siegert, F.: Spatiotemporal fire occurrence in Borneo over a period of 10 years, Glob. Change Biol., 15, 48-62, doi:10.1111/j.1365-2486.2008.01828.x, 2009.

Levine, J. S.: The 1997 fires in Kalimantan and Sumatra, Indonesia: Gaseous and particulate emissions, Geophys. Res. Lett., 26(7), 815-818, 1999.

Liu, C. J., Hannu, I., Björn, B., Werner, K., Yang, Y. S., Ma, X. Q., and Carl, J. W.: Aboveground litterfall in Eurasian forests, J. Forest. Res., 14(1), 27-34, 2003.

Matthews, E.: Global litter production, pools, and turnover times: Estimates from measurement data and regression models, J. Geophys. Res., 102(D15), 18771-18800, 1997.

Michel, C., Liousse, C., Grégoire, J. M., Tansey, K., Carmichael, G. R., and Woo, J. H.: Biomass burning emission inventory from burnt area data given by the SPOTVEGETATION system in the frame of TRACE-P and ACE-Asia campaigns, J. Geophys. Res., 110(D9), D09304, doi:10.1029/2004JD005461, 2005.

Page, S. E., Siegert, F., Rieley, J. O., Boehm, H. D. V., Jaya, A., and Limin, S.: The amount of carbon released from peat and forest fires in Indonesia during 1997, Nature, 420, 61-65, 2002.

Rieley, J. O. and Page S. E. (eds): Wise Use of Tropical Peatlands: Focus on Southeast Asia, Alterra-Wageningen University and Research Centre and the EU INCO-STRAPEAT and RESTORPEAT Partnerships, Wageningen, The Netherlands, online available at: www.restorpeat.alterra.wur.nl/download/WUG. pdf, 2005.

Roy, D. P. and Boschetti, L.: Southern Africa validation of the 
MODIS, L3JRC and GlobCarbon burned-area products, IEEE Geosci. Remote Sens., 47(4), 1032-1044, 2009.

Roy, D. P., Boschetti, L., Justice, C. O., and Ju, J.: The collection 5 MODIS burned area product-Global evaluation by comparison with the MODIS active fire product, Remote Sens. Environ., 112(9), 3690-3707, 2008.

Roy, D. P., Lewis, P., and Justice, C. O.: Burned area mapping using multi-temporal moderate spatial resolution data-A bi-directional reflectance model-based expectation approach, Remote Sens. Environ., 83, 263-286, 2002.

Seiler, W. and Crutzen, J. P.: Estimates of the gross and net fluxes of carbon between the biosphere and the atmosphere from biomass burning, Climatic Change, 2, 207-247, 1980.

Setzer, A. W. and Pereira, M. C.: Amazonia biomass burnings in 1987 and an estimate of their tropospheric emissions, Ambio, 20(1), 19-22, 1991.

Shea, R. W., Shea, B. W., Kauffman, J. B., Ward, D. E., Haskins, C. I., and Scholes, M. C.: Fuel biomass and combustion factors associated with fires in savanna ecosystems of South Africa and Zambia, J. Geophys. Res.-Atmos., 101, 23551-23568, 1996.

Shimada, S., Takahashi, H., Kaneko, M., and Haraguchi, A.: The estimation of carbon resource in a tropical peatland: a case study in Central Kalimantan, Indonesia, in: Proceedings of the International Symposium on Tropical Peatlands, edited by: Iwakuma, T., Inoue, T., Kohyama, T., et al., 22-23 November 1999, Bogor, Indonesia, Sapporo/Jakarta, Hokkaido University/Indonesian Institute of Sciences, 9-18, 2000.

Shrestha, B. M. and Singh, B. R.: Soil and vegetation carbon pools in a mountainous watershed of Nepal, Nutr. Cycl. Agroecosyst., 81, 179-191, 2008.

Singh, J. S. and Yadava, P. S.: Seasonal variation of composition, plant biomass, and net primary productivity of a tropical grassland at Kurukshetra, India, Ecol. Monogr., 44, 351-376, 1974.

Streets, D. G., Yarber, K. F., Woo, J.-H., and Carmichael, G. R.: Biomass burning in Asia: Annual and seasonal estimates and atmospheric emissions, Global Biogeochem. Cy., 17(4), 1099, doi:10.1029/2003GB002040, 2003.

Supardi, A., Subekty, D., and Neuzil, S. G.: General geology and peat resources of the Siak Kanan and Bengkalis Island peat deposits, Sumatra, Indonesia, in: Modern and Ancient Coal Forming Environments, edited by: Cobb, J. C. and Cecil, C. B., Geological Society of America Special Paper, 86, 45-61, 1993.
Tansey, K., Grégoire, J. M., Binaghi, E., Boschetti, L., Brivio, P. A., Ershov, D., Flasse, S., Fraser, R., Graetz, D., Maggi, M., Peduzzi, P., Pereira, J., Silva, J., Sousa, A., and Stroppiana, D.: A global inventory of burned areas at $1 \mathrm{~km}$ resolution for the year 2000 derived from SPOT VEGETATION data, Climatic Change, 67, 345-377, 2004.

Tansey, K., Grégoire, J.-M., Defourny, P., Leigh, R., Pekel, J.-F., van Bogaert, E., and Bartholomé, E.: A new, global, multiannual (2000-2007) burnt area product at $1 \mathrm{~km}$ resolution, Geophys. Res. Lett., 35, L01401, doi:10.1029/2007GL031567, 2008.

Vadrevu, K. P., Badarinath, K. V. S., and Anuradha, E.: Spatial patterns in vegetation fires in the Indian region, Environ. Monit. Assess., 147(1), 1-13, 2008.

van der Werf, G. R., Dempewolf, J., Trigg, S. N., Randerson, J. T., Kasibhatla, P. S., Giglio, L., Murdiyarso, D., Peters, W. Morton, D. C., Collatz, G. J., Dolman, A. J., and DeFries, R. S.: Climate regulation of fire emissions and deforestation in equatorial Asia, P. Natl. Acad. Sci. USA, 105, 20350-20355, 2008.

van der Werf, G. R., Randerson, J. T., Giglio, L., Collatz, G. J., Kasibhatla, P. S., and Arellano Jr., A. F.: Interannual variability in global biomass burning emissions from 1997 to 2004, Atmos. Chem. Phys., 6, 3423-3441, 2006, http://www.atmos-chem-phys.net/6/3423/2006/.

Venkataraman, C., Habib, G., Kadamba, D., Shrivastava, M., Leon, J.-F., Crouzille, B., Boucher, O., and Streets, D. G.: Emissions from open biomass burning in India: integrating the inventory approach with higher solution Moderate Resolution Imaging Spectroradiometer (MODIS) active fire and land count data, Global Biogeochem. Cy., 20, GB2013, doi:10.1029/2005GB002547, 2006.

Yevich, R. and Logan, J. A.: An assessment of biofuel use and burning of agricultural waste in the developing world, Global Biogeochem. Cy., 17(4), 1095, doi:10.1029/2002GB001952, 2003.

Yokelson, R. J., Karl, T., Artaxo, P., Blake, D. R., Christian, T. J., Griffith, D. W. T., Guenther, A., and Hao, W. M.: The Tropical Forest and Fire Emissions Experiment: overview and airborne fire emission factor measurements, Atmos. Chem. Phys., 7, 5175-5196, 2007, http://www.atmos-chem-phys.net/7/5175/2007/.

Zinke, P. J., Stangenberger, A. G., Post, W. M., Emanuel, W. R., and Olson, J. S.: Worldwide organic soil carbon and nitrogen data, ORNL/TM-8857, Oak Ridge National Laboratory, Oak Ridge, TN, 141, 1984. 